\title{
الأمن النفسي لدى الأبناء
}

$$
\begin{aligned}
& \text { (إعاد } \\
& \text { الباحث/ يوسف على محمد أحمد محمد الكندري }
\end{aligned}
$$

$$
\text { إسر افـ }
$$

أ ـ د/ حسين محمد سعداللدين الحسيني

أستاذ علم النفس

بكليتالآداب - جامعتماذ المنصورة

$$
\begin{aligned}
& \text { المجلت العلميت لكليت رياض الأطفالـ جامعت المنصورة } \\
& \text { المجلد الثالث_ العدد الثالث }
\end{aligned}
$$

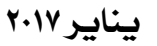




\section{الأمن النفسي لدى الأبناء}

$* *$

أر يوسف على محمدد أحمد محمد الكندري

مفهوم الأمن النفسي

مفهوم الأمن النفسي من المفاهيم المركبة في علم النفس، و يتداخل في

مؤشر اته مع مفاهيم أخرى مثل الطمأنينة الانفعالية، الأمن الذاتي، التكيف الذاتي،

الرضا عن الذات، مفهوم الذات الإيجابي، التوازن الانفعالي.. الخ، كم يتبادل في

الو اقع عندما يكون الحديث عن مستو اه في الدر اسات النفسية مع مفاهيم (القلق،

الصر اع، الثُعور بعدم الثقة، توقع الخطر ، الإحساس بالضغط، الإحساس بالعزلة

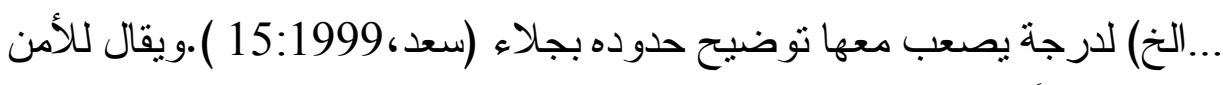

النفسي أيضاً "الأمن الانفعالي و "الأمن الثخصي " و " الأمن الخاص" و السلم

الشخصي( "ززر ان،1989 :296).

تعريفات الأمن

أولاً: تعريف الأمن النفسي في اللغة :

يعد مفهوم الأمن من المفاهيم اللغوية ذات الثر اء في المعنى فقد جاءت كلمة

أمن في كل من لسان العرب و المعجم الوسيط ومختار الصحاح بعدة معانِ نذكر

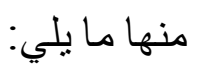

الأمن الذي هو ضد الخوف، يقال: أمن أمناً و أماناً و أمنه: إذا اطمأن، ولم

يخف، فهو آمن، و أصل (الأمن) طمأنينة في النفس، وزو ال الخوف عنها؛ يقال: 
أمن بأمن أمناً وأمنه و أماناً. و المأمن: موضع الأمن. و الأمن: اسم من أمنت.

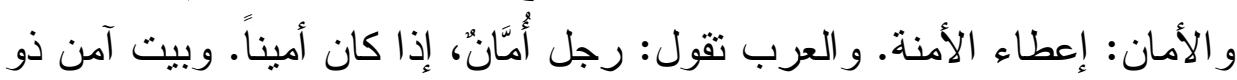

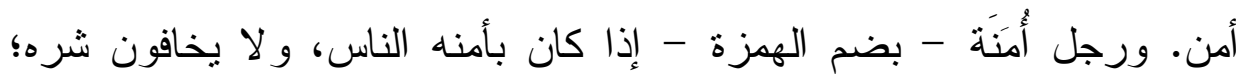

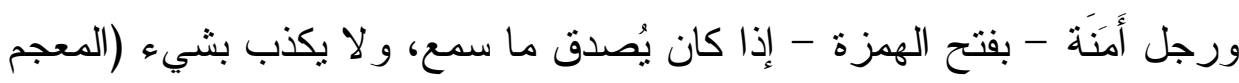

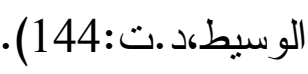

ولفظ (الأمن) تارة يكون اسماً للحالة التي يكون عليها الإنسان في الأمن ، لئل

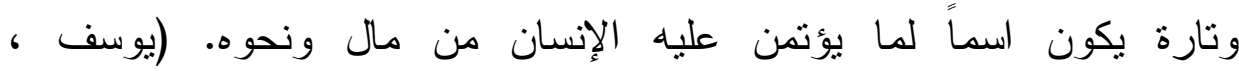

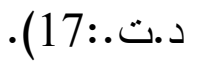

ورد في لسان العرب لابن منظور: (الأمان و الأمانة بمعنىً، وقد أمنت

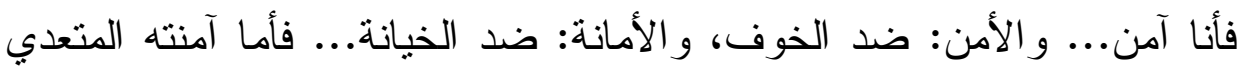

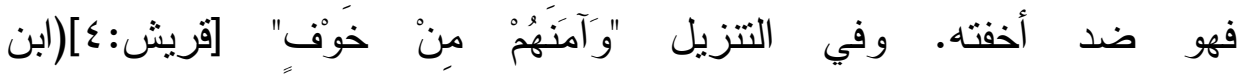

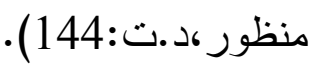

من هو الثخص الأمن؟ هو الثخص الذي يشعر أن حاجاتهُ مشبعة وأن المقومات الأساسية لحياته غير معرضة للخطر ويكون في حالة تو ازن أو نو افق القن أمني. ثانيا: التعريف الاصطلاحي:

عرفه زهران بأنه الطمائنينة النفسية أو الانفعالية وهو الأمن الثخصي أو

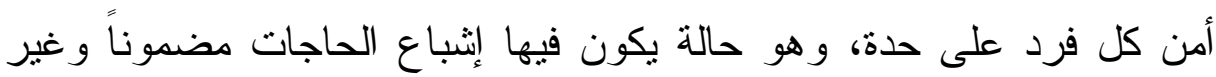
معرض للخطر وهو محرك الفرد لتحقيق، أمنه وترتبط الحاجة إلى الأمن ارتباطا وثثقاً بغريزة المحافظة على البقاء.( زهران ، 329:1990) فيعرفه بقوله: "كون المرء آلمناً، أي سالماً من تهديد أخطار

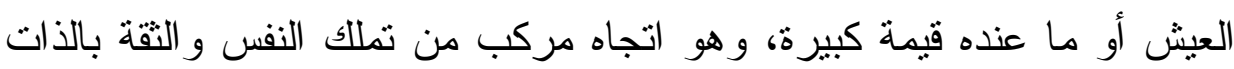


و التيقن من أن المرء ينتمي لجماعات إنسانية لها قيمتها"ويرى أن الأمن: حالة

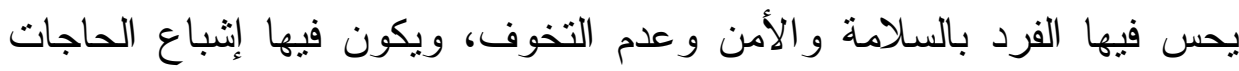

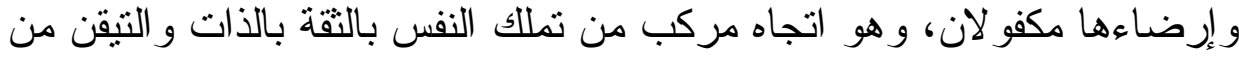
أن المرء ينتمي إلى جماعات إنسانية لها قيمة.ويتفق (الدسوقي، 1990:129 ) في تعريف الأمن النفسي مع زهران فيرى أن معنى الأمن النفسي: هو الأمن النماتية

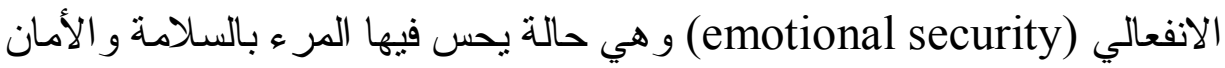
و عدم التخوف والإثفاق على المستقبل وهي حال يكون فيها إنثباع الحاجات

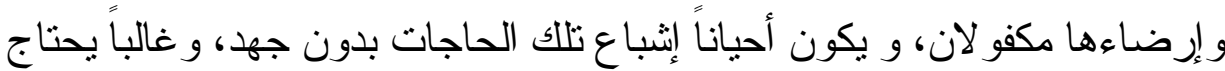
إلى المجاهدة المعقولة، و التي سوف تجلب الرضا ـ و هو اتجاه مركب من تملك النفس بالثقة بالذات و التيقن من أن المرء ينتمي إلى جماعات إنسانية لها قيمتها

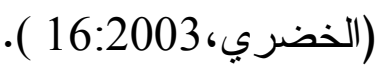

ويعرفه ( الصنيع، 1995: 70) أنه سكون النفس وطمأنينتها عند تعرضها لأزمة تحمل في ثناياها خطراً من الأخطار، كنلك شعور الفرد بالحماية من الفن

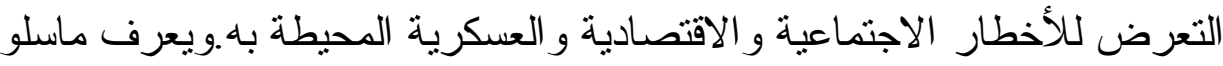

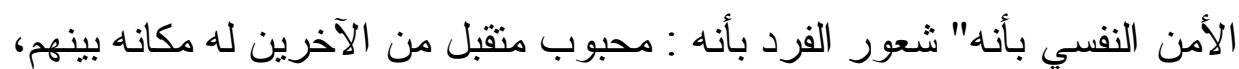

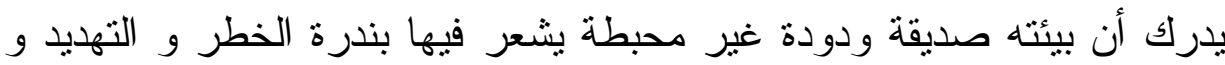

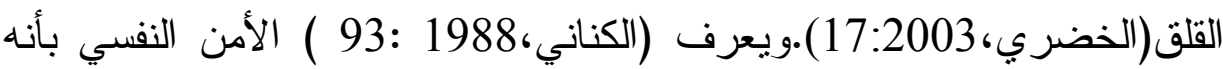
مقدار ما يحتاج إلية الفرد من حماية لنفسه، ووقايتها من الظروف التي تتكل خطر ال التران

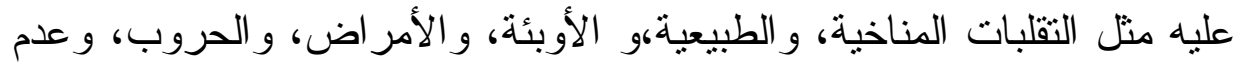

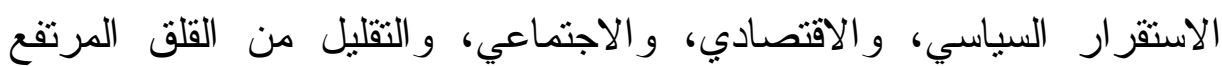
المصاحب للمستقبل المجهول سو اء فيما يتعلق بدر استه، أو عمله، أو مأكله، أو الو الون

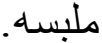


ويرى جبــ(جبر، 1996 : 80) أن الإحساس بالأمن النفسي مرتبط

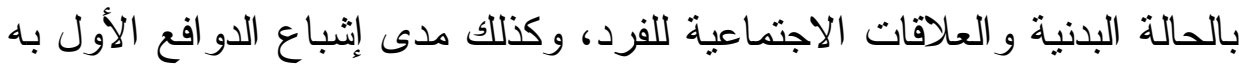

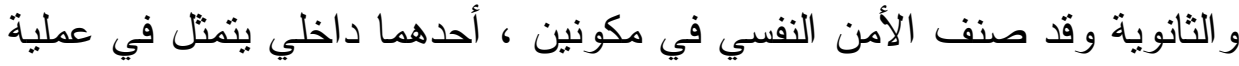

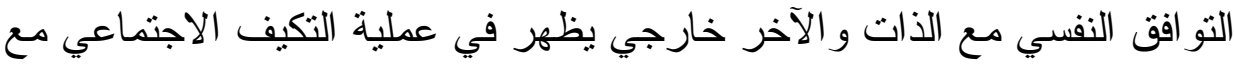

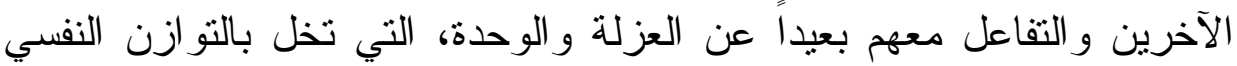
للشباب و المر اهقين وتؤثر على مستوى تو افقهم الاجتماعي. كي يشعر الإنسان بالأمن النفسي، فانه في ذلأك شأن الأمن الصحي، الأني،

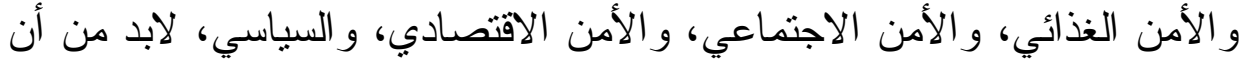

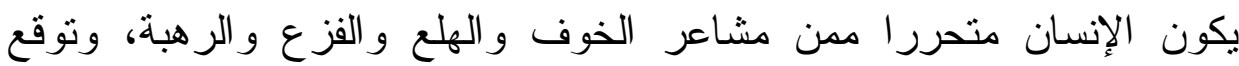

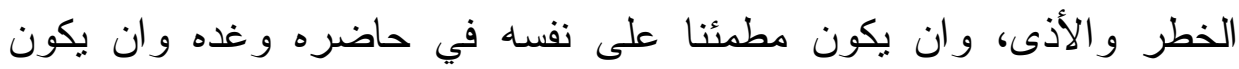

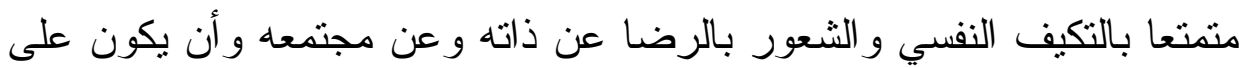
علاقة وئام و انسجام مع نفسه ومع المجتمع (العيسوي، 407:2002 ). وبعد أن استعرضت الباحث هذه التعريفات المتعددة للأمن النفسي ترى

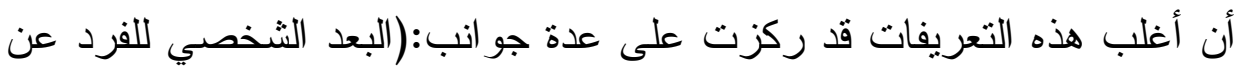

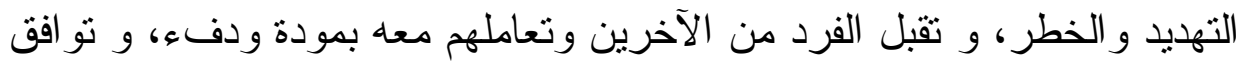

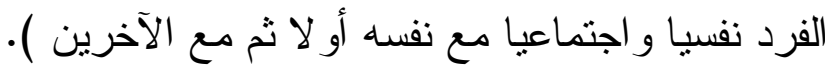
و عليه فان الطمأنينة حاجة نفسية إنسانية لا تستقيم حياة وشخصية الإنسان

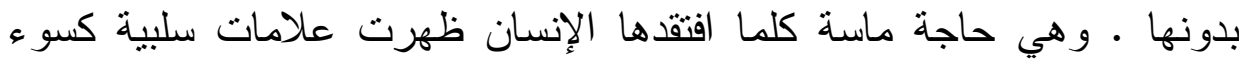
النو افق النفسي.ليست مطالب النفس البشرية، هي الغرائز الأولية فقط (تنفس أكل ـ شرب ـ تتاسل)، بل هنالك العديد من مطالب النفس، التي يحتاج الإنسان

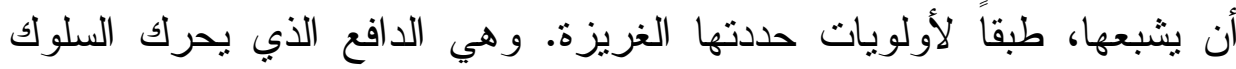

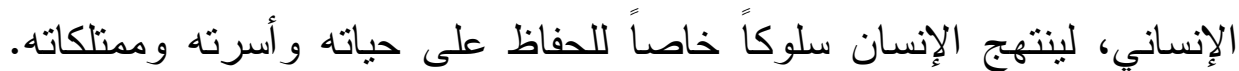

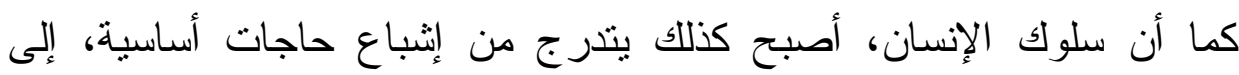


حاجات ثانوية، إلى مطالب تحقيق الذات، إلى مطالب رفاهية. ثم تعلو الدرجات

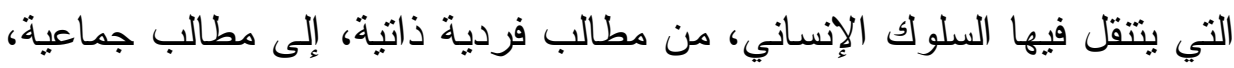
تحتاجها الأسرة و الجماعة، فالقبيلة، فالقرية فالمدينة، فالدولة، حتى يصبح الثعور الأمن جماعياً أيضاً.

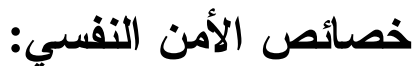

إن الثعور بالأمن النفسي ينشأ وينمو مع الفرد على أساس الإشباع النسبي

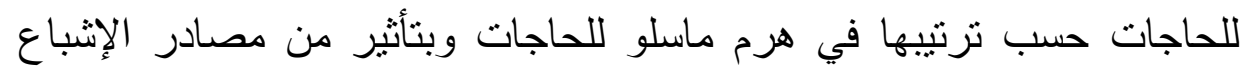

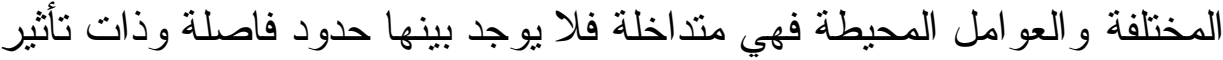
متباين وقوي من حيث المقدار و النوع في مر احل العمر المختلفة. كما تشكل ثقافة

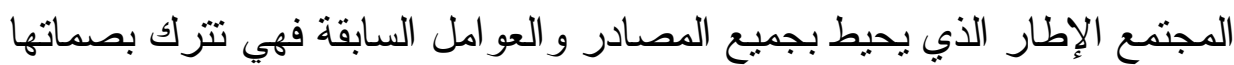

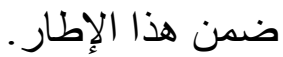
خصائص الأمن النفسي استتاداً كما أثنار إليها(زهر ان،

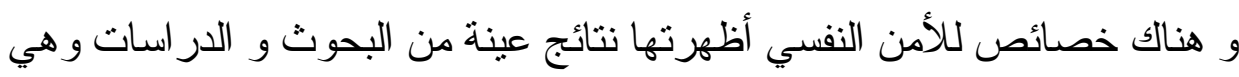

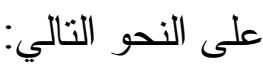

•يتحدد الأمن النفسي بعملية التتشئة الاجتماعية، و أساليبها من تسامح، و و

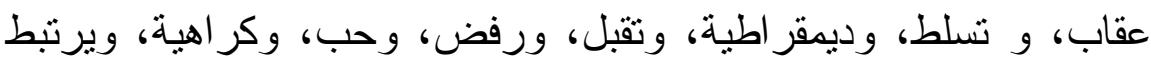

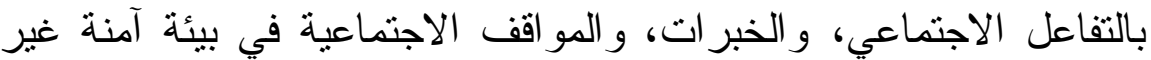

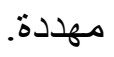

• يؤثر الأمن النفسي إيجابياً على التحصيل الدراسي وفي الإنجاز بصفة عامة. • • المتعلمون و المثقفون أكثر أمناً من الجهلة و الأميين.

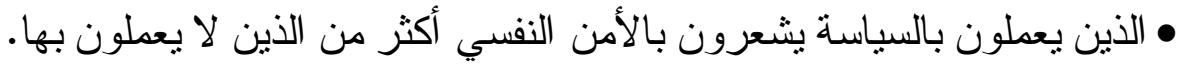

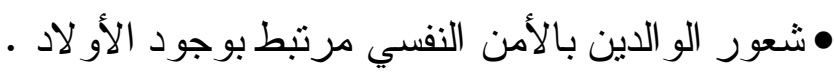
• الأمنون نفسياً أعلى في الابتكار من غير الأمنين. 
• عدم الأمن يرتبط موجباً بالدوجماطية أي التشبث بالر أي و الجمود الفكري

$$
\text { بدون مناقشة أو تقكير . }
$$

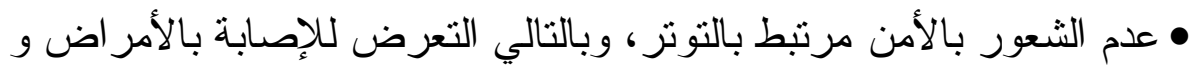

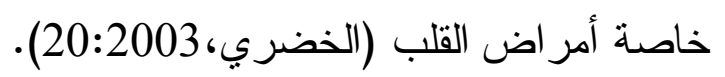

حاجة الفرد إلى الأمن النفسي

الحاجة إلى الأمن من أهم الحاجات النفسية. ومن أهم دو افع السلوك طو ال الكي الحياة. وهى من الحاجات الأساسية اللازمة للنمو النفسي السوي و التنو افق النفسي

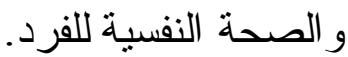

ويذكر زهران أن الحاجة إلى الأمن هي محرك الفرد لتحقيق أمنه،

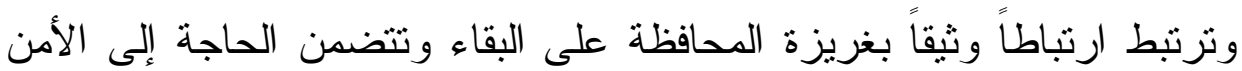

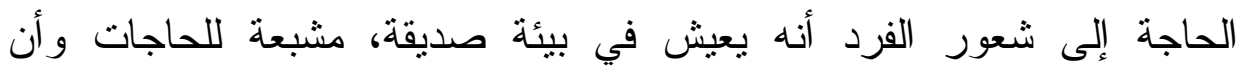
الآخرين يحبونه ويحترمونه ويقبلونه داخل الجماعة، وأنه مستقر و آمن أسرياً،

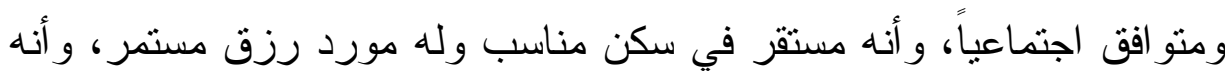

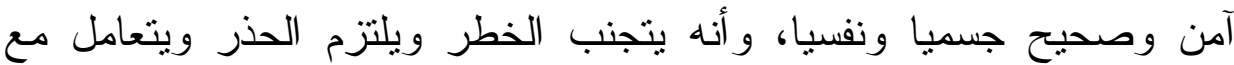
الأزمات بحكمة وبأمن الكوارث الطبيعية، ويشعر بالتقة والاططئنان والأمن

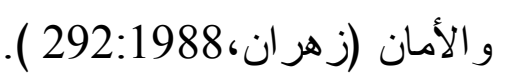

ويذهب سوليفان إلي أن هدف الإنسان هو خفض التوتر الذبي بهدد أمنه،

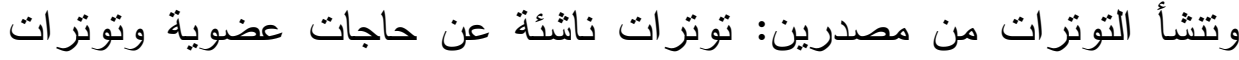
تتشأ من مشاعر القلق، وخفض التوتزات النانشئة عن القلق بعتبر ن العمليات الهامة في نظرية سوليفان و التي أطلق عليها "مبدأ القلق"، و القلق في نظر سوليفان هو أحد المحركات الأولية في حياة الفرد (عثمان، 2001: 38). و الأمن النفسي من أهم الحاجات الأساسية اللازمة للنمو النفسي السوي

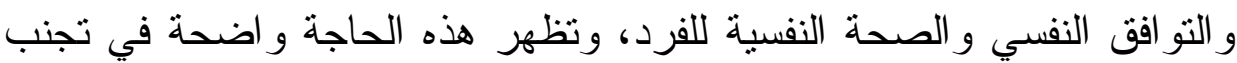

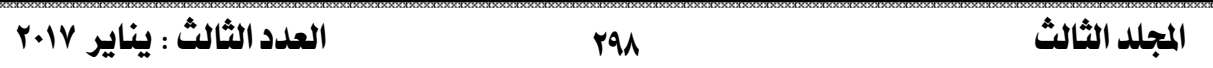


الخطر و المخاطرة وفي اتجاهات الحذر و المحافظة، وتتضح الحاجة إلى الأمن في الطفل الذي يحتاج رعاية الكبار حتى بستطيع البقاء. الحاجة الانتماء الأسري، و الانتماء إلى الجماعة (الأصدقاء) و الانتماء إلى الوطن الوناء ـ من خلال

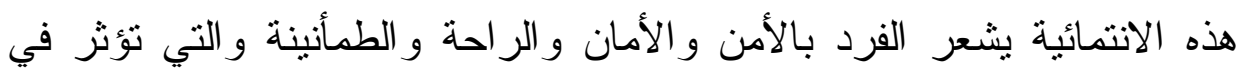

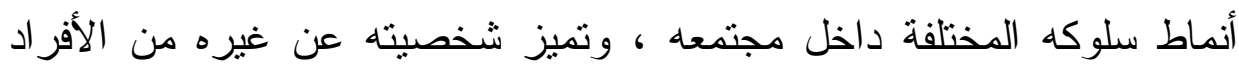

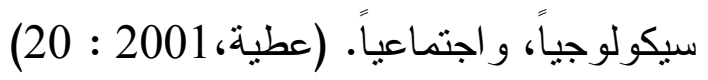

وتعد الحاجة إلى الأمن كالحاجات الفسيولوجية حاجة أولية من حيث نشأتها،

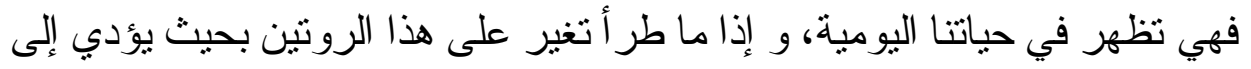

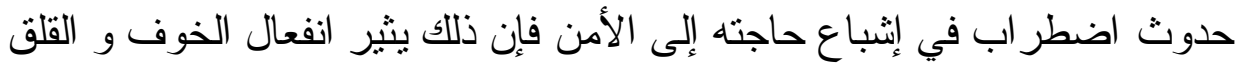

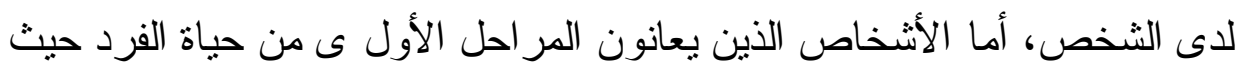

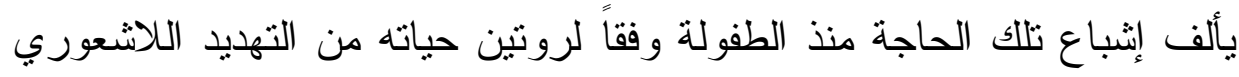

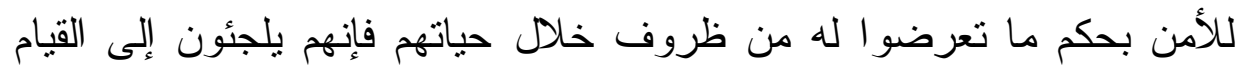

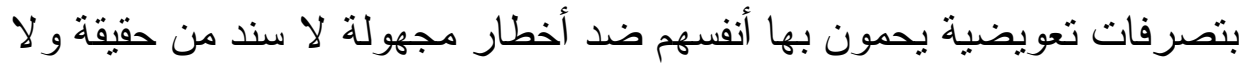

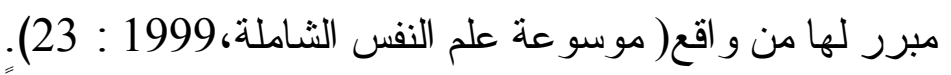
ويعتبر الأمن النفسي من الحاجات المهمة والضرورية التي لا بد من التهري

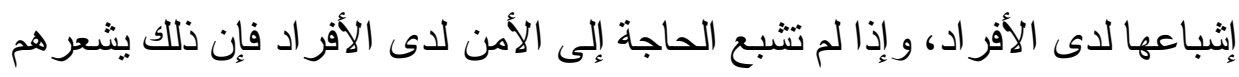
بالتهديد و لا يمكن أن يحققو ا ذو اتهم.

ولقد أثنار ماسلو Maslow ( 39-43 : 1970 )إلى أهمية الثعور بالأمن النفسي في هذا العالم الذي يتصف بالحروب و الكوارث و الأزمات الاقتصادية و انتشار البطالة و الخوف من المستقبل مما يجعل الطفل يشعر بالقلق و العجز و الئس.

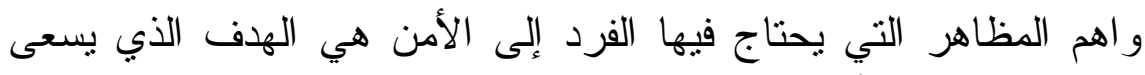

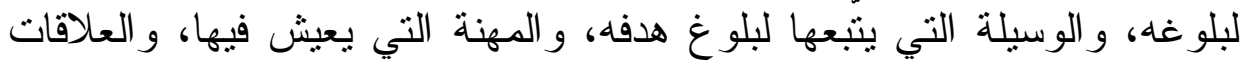




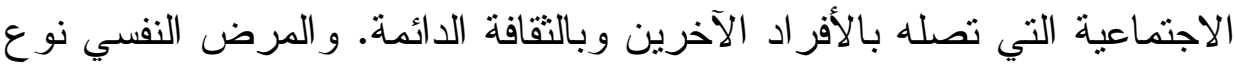

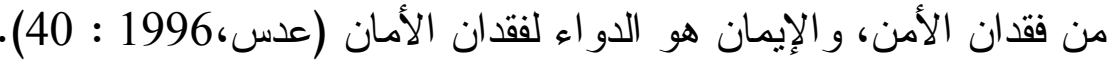
ويحتاج الأفر اد- كافة الأفر اد - أن يكون هذا المفهوم مفهوم الذات لديهم

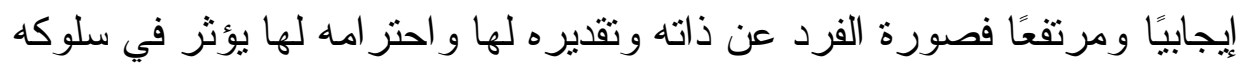

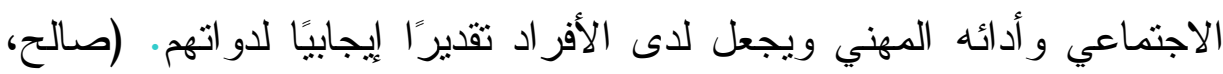
.216:1994

يقول (الزحيلي،1993: 146 ) و وتتعدد صور الحاجة إلى الأمن في زماننا

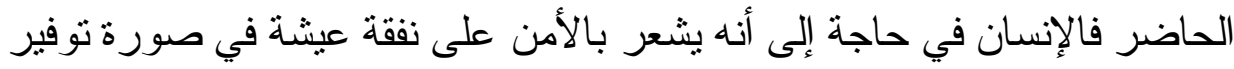

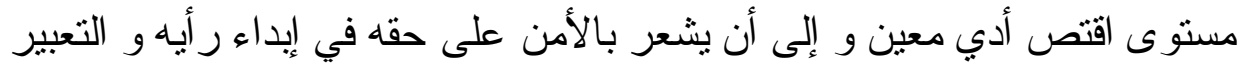

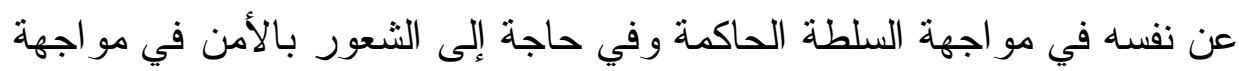

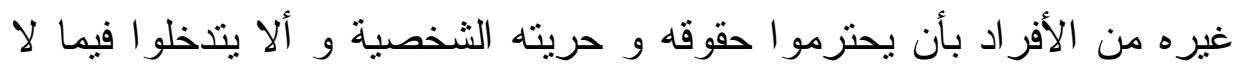

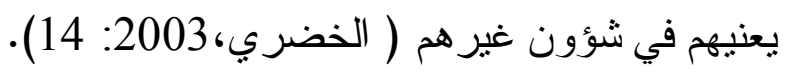
ومن هنا تحصر الباحث أهم الحاجات لتحقيق الأمن النفسي: 1. الحاجة إلى تأكيد الذات: يميل الفرد إلى معرفة وتحقيق ذاته بدافع من الحاجة إلى التقدير و المكانة والاستقلالية و الاعتماد على النفس. كلى كل هذه الحاجات وسواها تدفع الفرد إلى السعي لتحقيق المركز و المكانة و القيمة

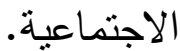
r. الحاجة إلى الحب: وهذه حاجة مشتركة لدى جميع الناس وتتشمل الحاجة

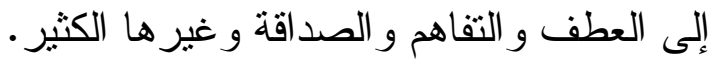
r. الحاجة إلى الأمان: وهي الحاجة إلى الثعور بأن البيئة الاجتماعية بيئة صديقة، وشعور الفرد أن الآخرين يحترمونه ويقبلونه داخل الجماعة. وتظهر هذه الحاجة واضحة في تجنب الخطر و المخاطرة وفي اتجاهات الحذر و المحافظة. وتتضح الحاجة إلى الأمن في الطفل الذي يحتاج رعاية الكبار 
حتى يسنطيع البقاء ـ و الحاجة إلى الأمن تستوجب الاستقر ار الاجتماعي و الأمن الأسري ـ و الفرد الذي يشعر بالأمن والإثثباع في بيئته الاجتماعية المباشرة في الإني

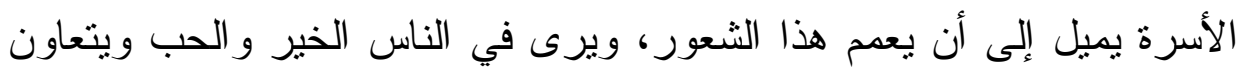
معهم و العكس صحيح. و الثخص الأمن يشعر بإثباع هذه الحاجة ويشعر بالثقة

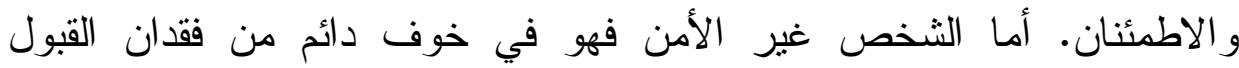

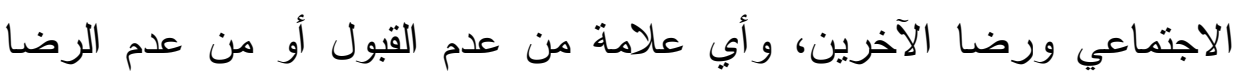

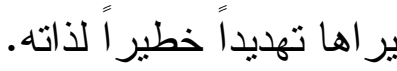

ومن وجهة نظر فرويد أن مقومات الطمأنينة الانفعالية هدف يسعى

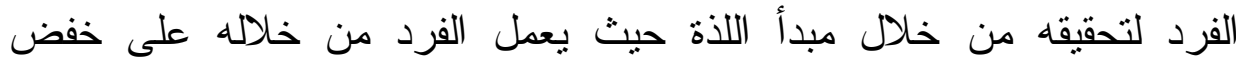
التوتز و استعادة تكامله وهدو وه عندما تثار المحفز ات ومصدر ها الغر ائز في رأي الئي التحليل النفسي.

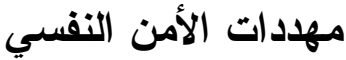

إن انعدام الثعور بالأمن قد يكون سبباً في حدوث الاضطر ابات النفسية، أو

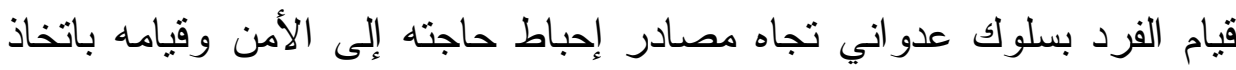
أنماط سلوكية غير سوية من أجل الحصول على الأمن الذي يفتقر إليه أو الانطو اء

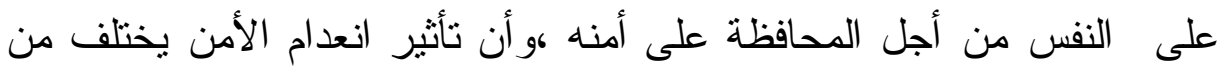

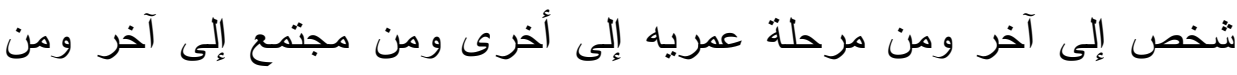
الأسباب التي تهدد الأمن النفسي للفرد نوجز ها التهن الباحث بما يلي:

1- الخطر أو التهايد بالخطر، مما يثير الخوف و القلق لدى الفرد. ويجعله

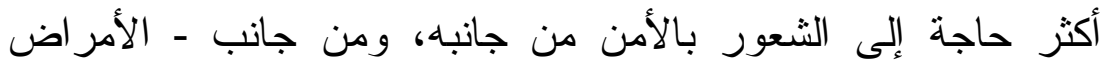

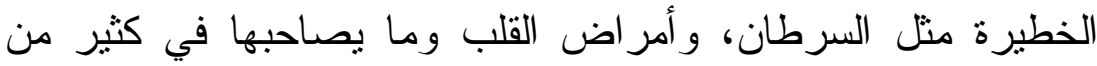

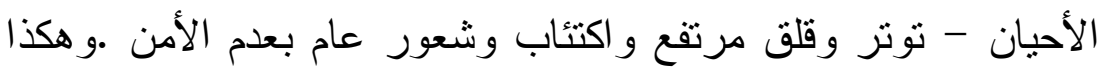

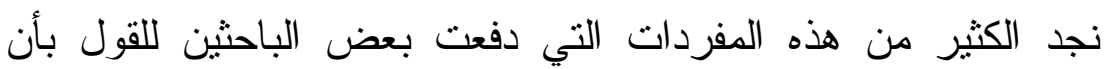


القانون و الدين و الأخلاق و الطب ما هي إلا وسائط ما وجدت إلا لأجل

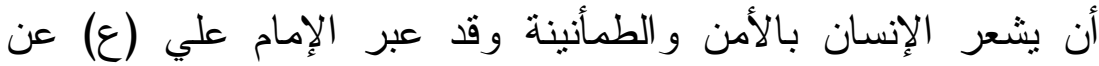

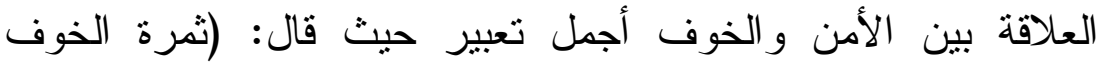

$$
\text { الأمن)( الثير ازي، 1993). }
$$

r- عو امل جسمية واجتماعية: للفرد حاجات لا بد من إثباعها ليكون منو افقاً

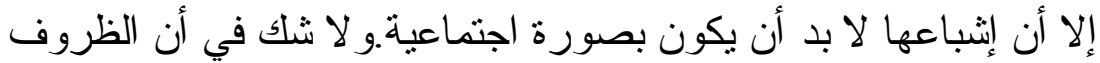

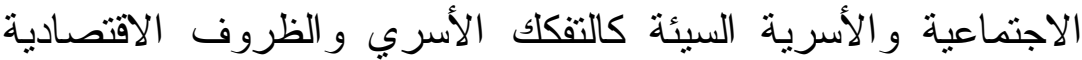

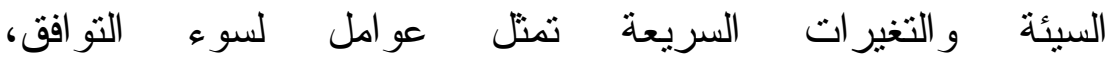
كما يقول عكاثة قد يلجأ بعض الأثخاص إلى اتخاذ الحلول الوسطية

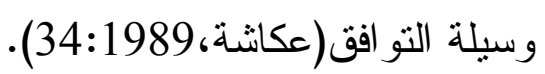

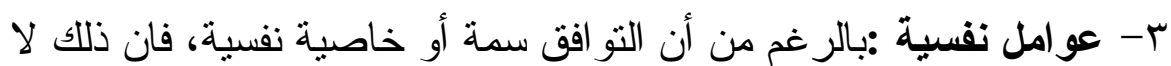

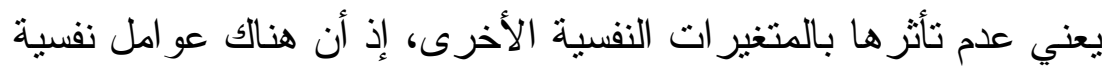

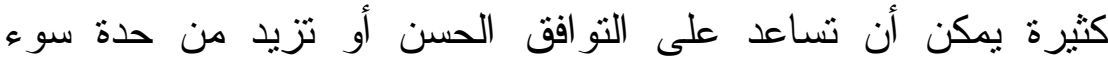
النو افق .

فالاضطر ابات النفسية عوامل ومظاهر لسوء التوافق، كما تعتبر عوامل مساعدة على إحداثه .ومنها على سبيل المثال لا الحصر : - الانفعالات الثديدة و الغير مناسبة للموقف حيث يكون لهذه الانفعالات الغير متو ازنة أثز ها السيئ من الناحية الجسمية و النفسية و الاجتماعية. - عدم فهم المرء لذاته أو التقدير السالب للأات وضعف مشاعر الكفاية يمكن أن تكون سببا لسوء التوافق، كما يمكن أن تعوق قدرة الفرد على تحديد

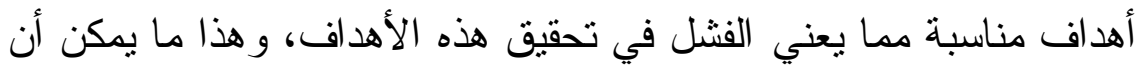

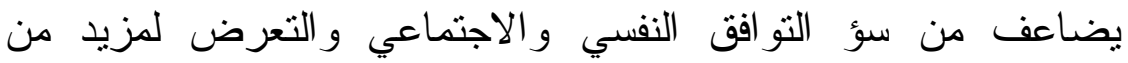

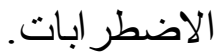


- صر اع الأدوار : يلعب الفرد أدواراً متعددة تبعاً لما يتوقعه المجتمع وقد

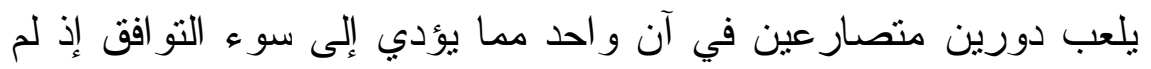

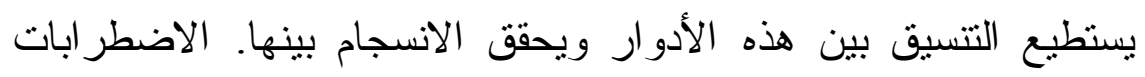
النفسية بكافة أنو اعها حيث سوء التو افق مظهر ا من مظاهر ها.

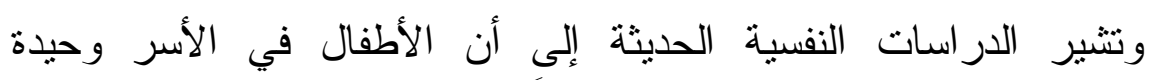

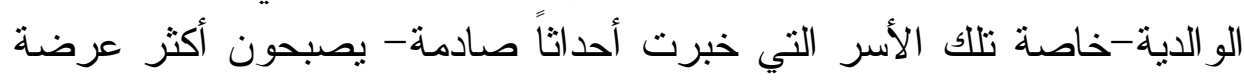

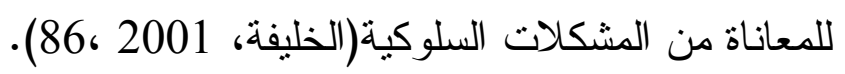

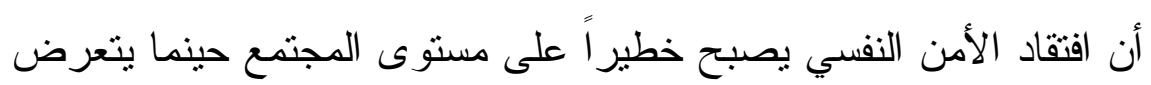

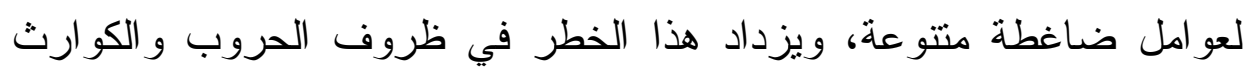

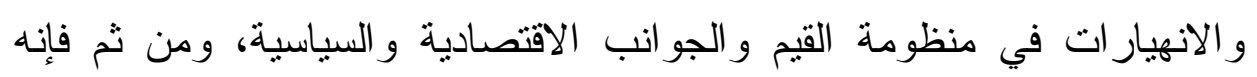

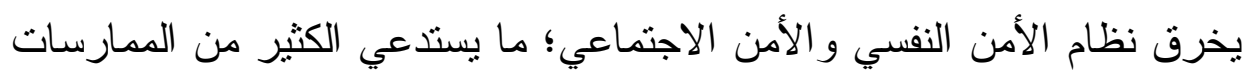

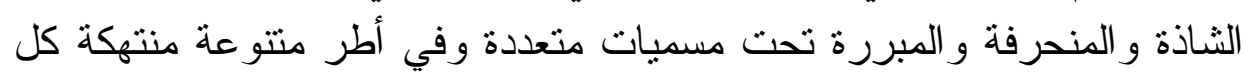

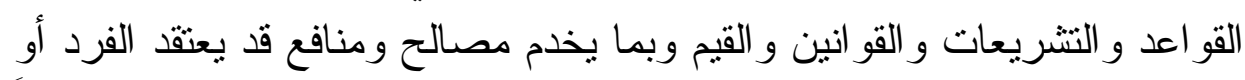

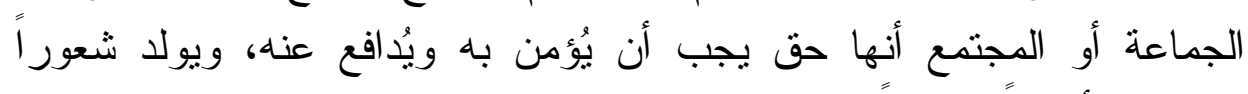
و عاطفة و أفكار أ وسلوكاً لا تتسجم مع المعايير سو اء كان ذلك على على مستوى الفرد أو الجماعة.

\section{الآثار المترتبة على انعدام الثعور بالأمن النفسي}

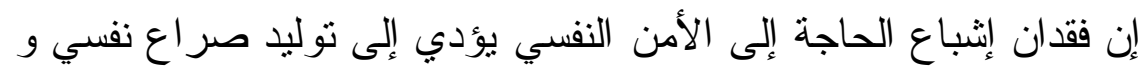

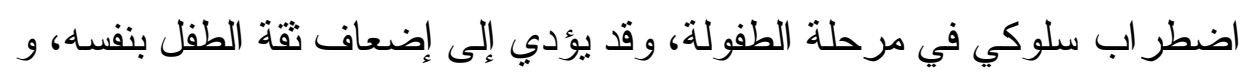

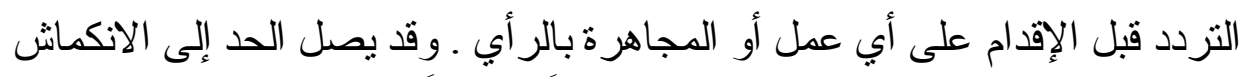

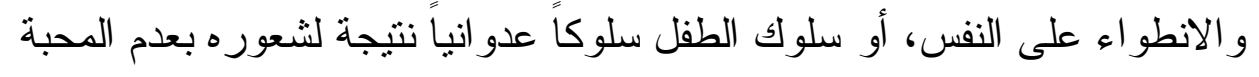

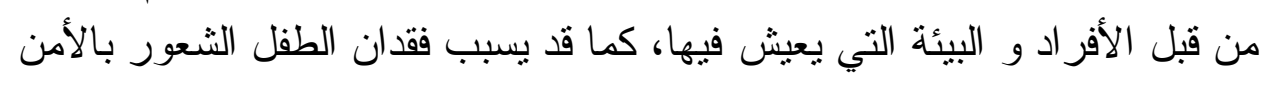

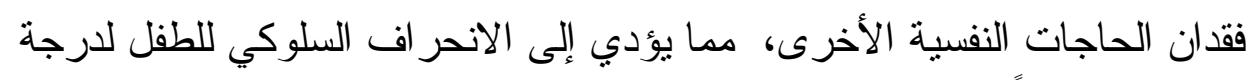
قد يصبح خطر اً على نفسه مجتمعه. 
ويشير (مرسي، 126:1981 ) إلى أن الحرمان من الأمن يختلف نأثيره على

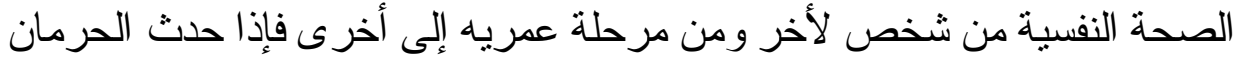

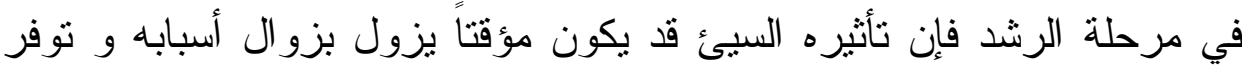

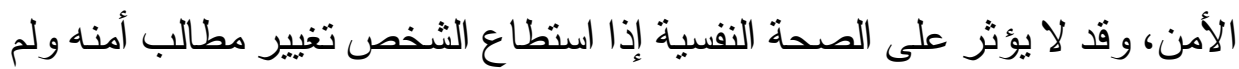

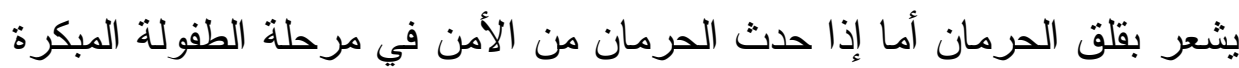

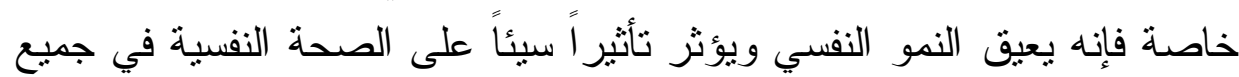
مر احل الحياة لأن الحرمان من الأمن يعنى تهديدا خطير الإثباع حاجيات الطيات الطفل

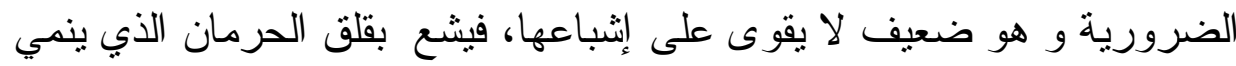
فيه سمات التو افق السيئ التي من أهمها سمات القلق و العداوة و الثعور بالذاعنب

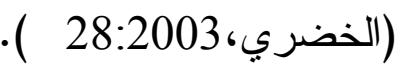

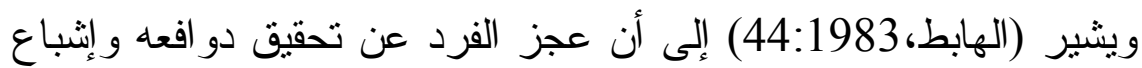

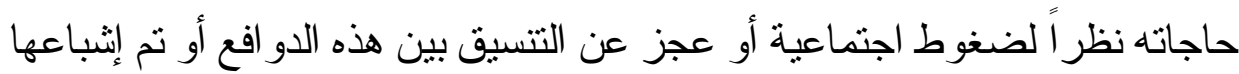

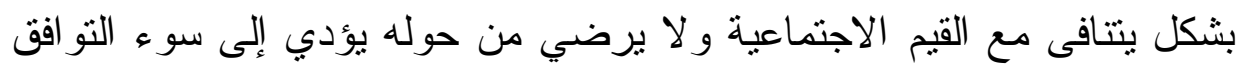
ويتعرض الفرد لاضطر ا بات نفسية. ويشير (راجح، 113:1973) إلى أن لسوء النو افق مظاهر متعددة ومختلفة

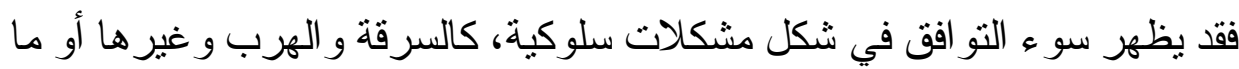
ينعرض المر اهقين من مشكلات كالتمرد و الانطو اءو وقد يشتد ويصبح أكثر خطورة

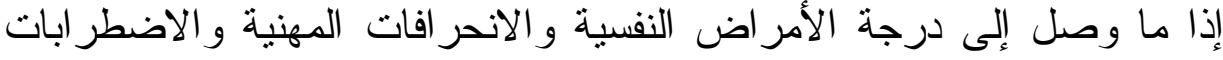
العقلية

ومما سبق يحصر الباحث الآثار المترتبة على انعدام الثعور بالأمن النفسي

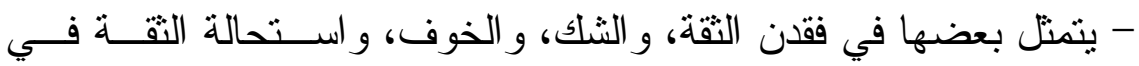
الآخرين و اللامبالاة و العدو ان و الكر اهية. 


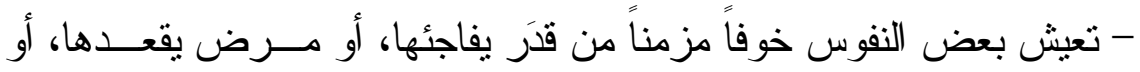

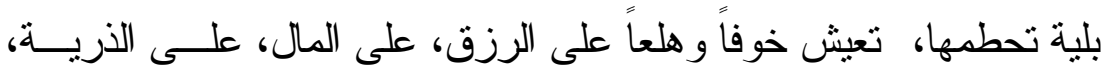

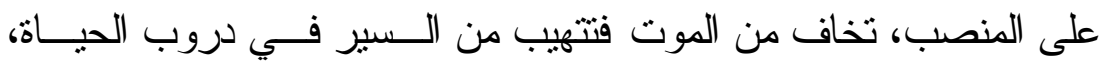

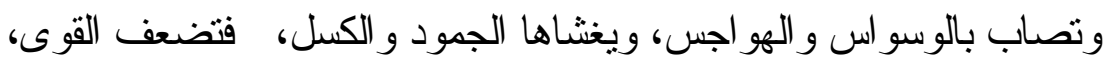

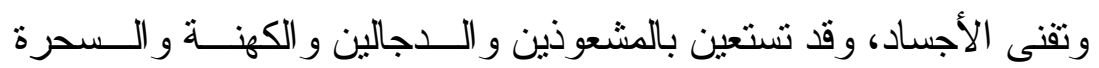
للخلاص من الوسوسة، ودرء الأخطار المحتملة.

\section{أساليب تحقيق الأمن النفسي:}

- يلجأ الفرد لتحقيق الأمن النفسي إلى ما يسمى "عمليات الأمسـن النفـسي"

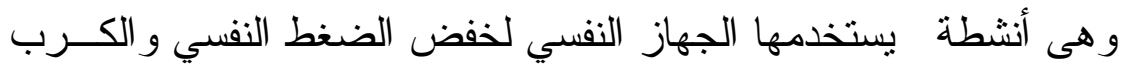
و التوتز و الإجهاد أو التخلص منه وتحقيق تقدير الذات و الثعور بالأمان.

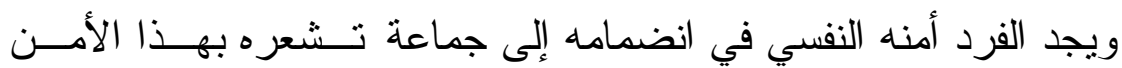

$$
\text { (ز هر ان، 2003: 200) }
$$

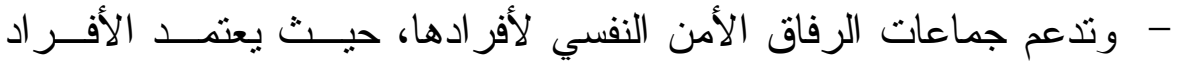

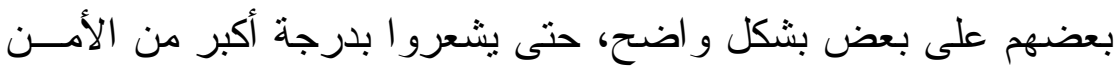
النفسي.

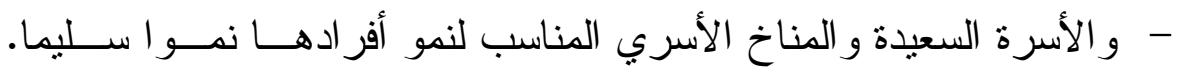

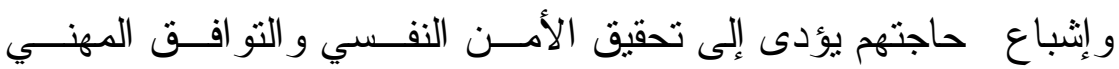

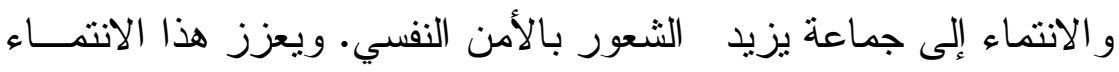

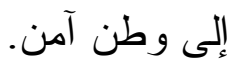

يذكر الثريف الأسرة هي التي تقوم بعملية التتشئة الاجتماعية للأبناء، وهذا يتم من خلال أساليب المعاملة الو الدية التي يتبعها الآباء في تتشئئة أبنائهم .وتعتبـــــر

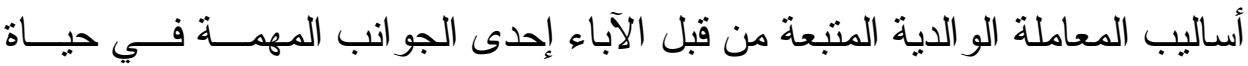

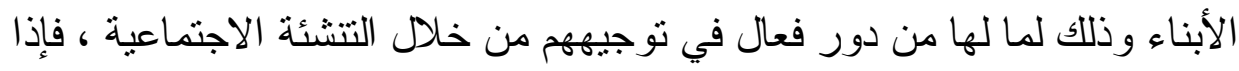




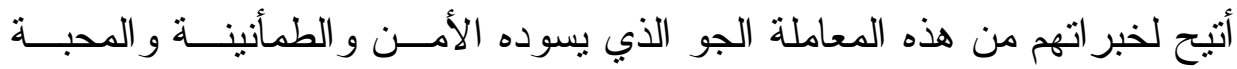

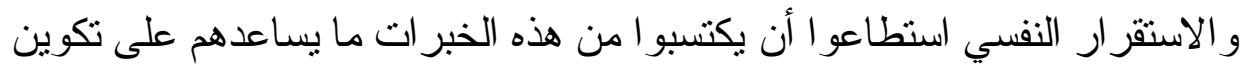

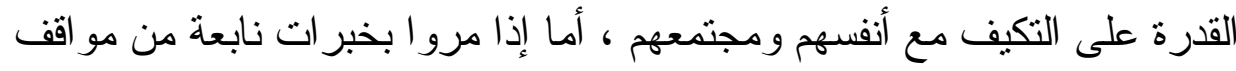
الحرمان فإن ذلك يؤدي إلى تكوين شخصية تعاني من عدم الطمأنينة، شخصية قلقة الفية

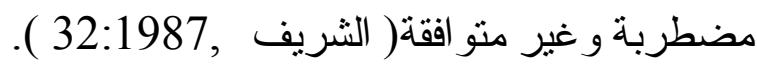

ويذكر ( صادق ،2790 1990 ) أن الو الدان يقومان بدور كبير في تـشكيل

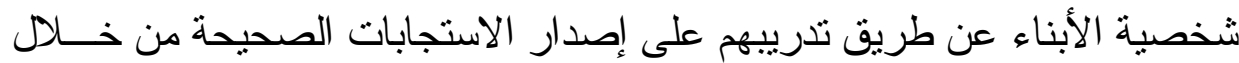

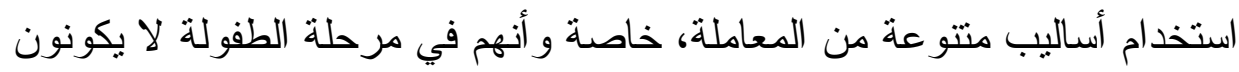

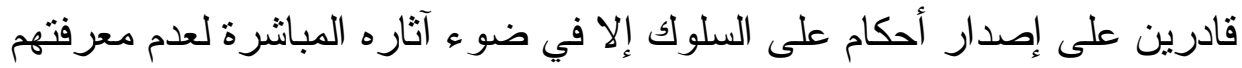

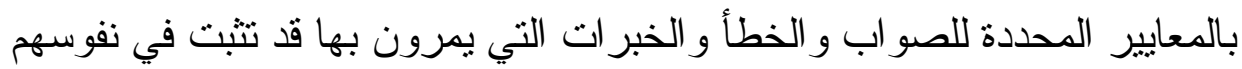

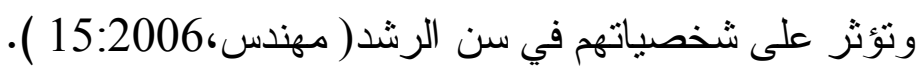
وقد أكدت أنستازى (Anastasia) على أهمية التفاعـلـل بــين الو الــدين

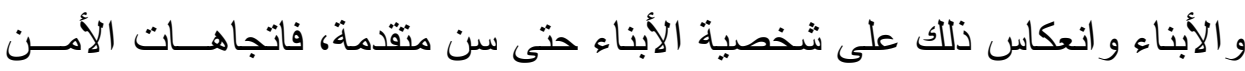
و الطمأنينة قد تستمر مع الطفل عند مو اجهة مو اقف إحباط شديدة آما أن اتجاهات

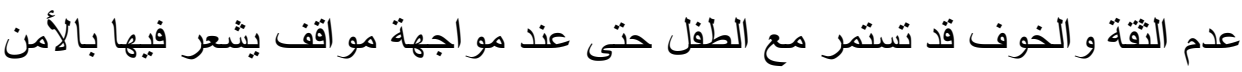

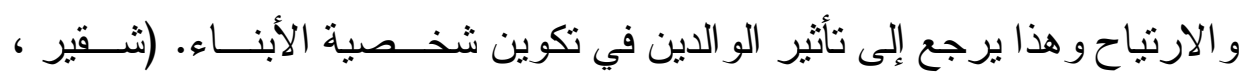
. 99 : 1996

\section{و لتحقيق الأمن النفسي يتعين على الفرد ما يلي:}

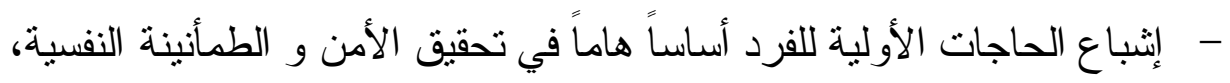

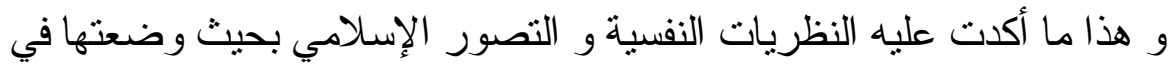

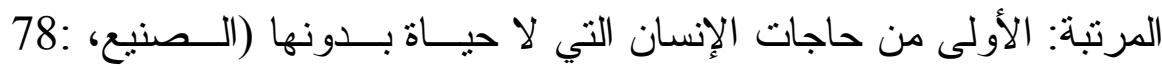




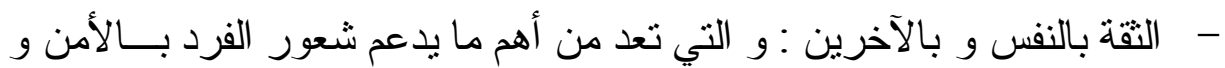

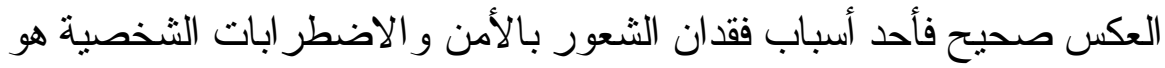

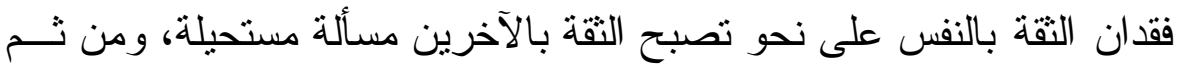

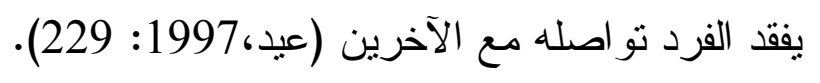

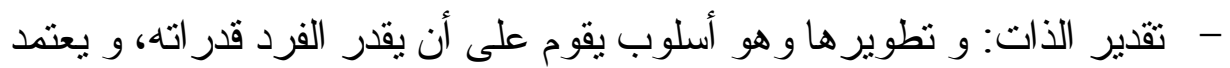

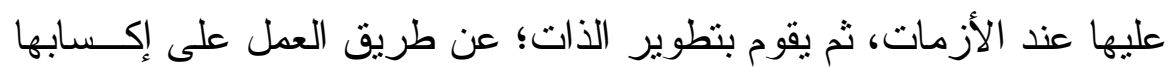

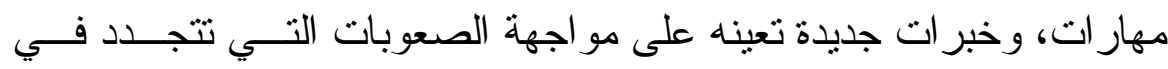
الحياة(الصنيع، 78:1995).

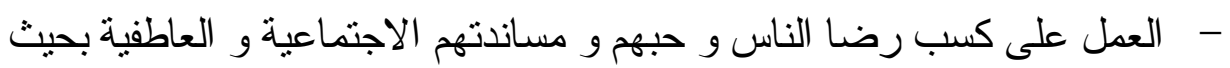

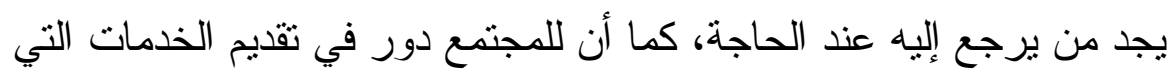

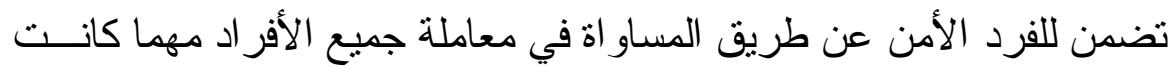

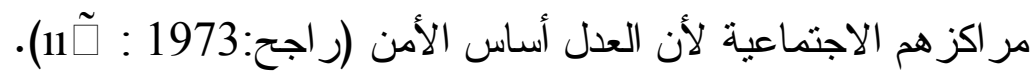

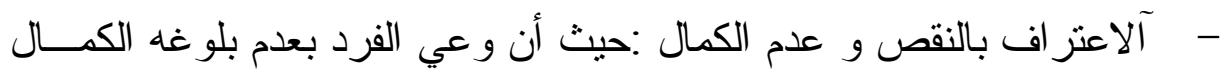

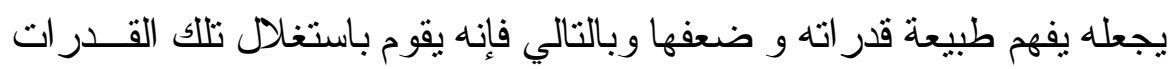

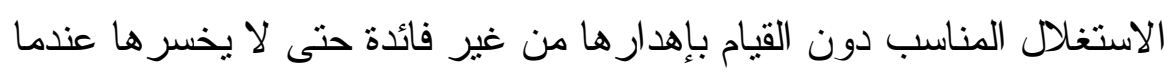

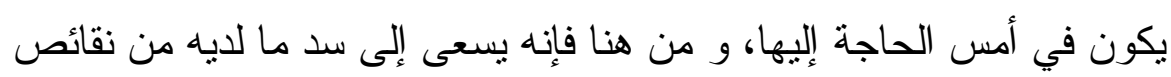

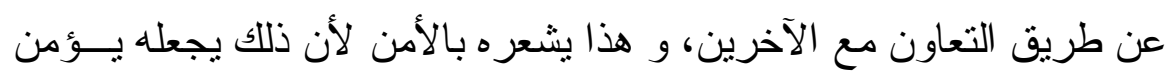

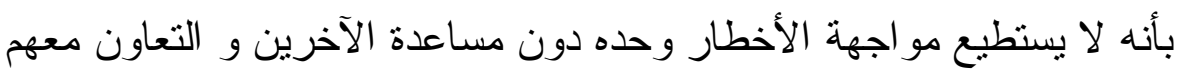

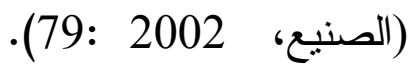
- معرفة حقيقة الو اقع :و هذا يقع على عاتق المجتمع وله الدور الكبير في توفيره

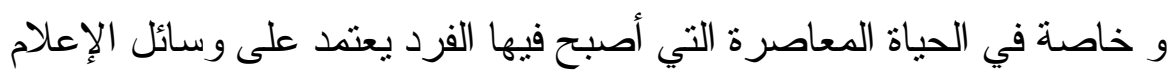

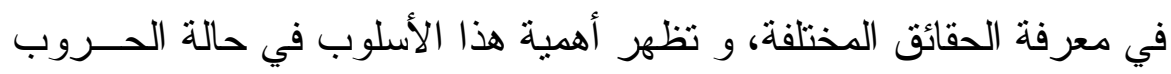

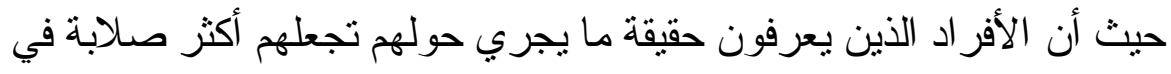


مو اجهة أزمات الحروب على عكس الأفر اد الدضللون الذين لا يعرفون مــــ

$$
\text { يحدث حولهم(الصنيع، 1995: 80). }
$$

يتضح مما سبق أن الثنعور بالأمن النفسي من أهم الدعائم التي ترتكز عليها

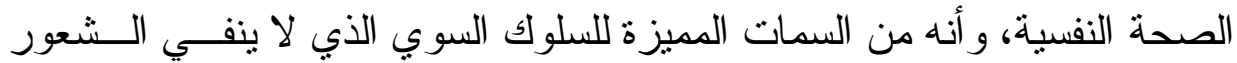
بالقلق و الخوف و الصر اع بصورة منوقعة من أجل إز الة مصادرهو و مسسيباته و العودة إلى حالة الاتز ان النفسي، لذا يتضح أن الأمن النفسي لا يكون ثابتاً مطلقاً و النا

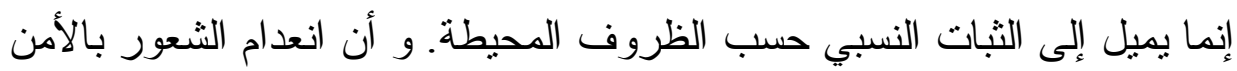
قد يكون سبباً في حدوث الاضطر ابات النفسية، أو قيام الفرد بسلوك عدو الفي الفي تجاد الفياه

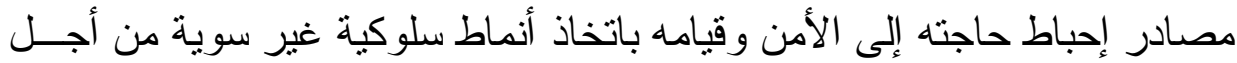

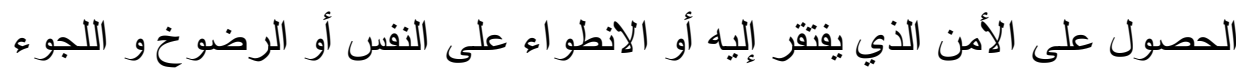

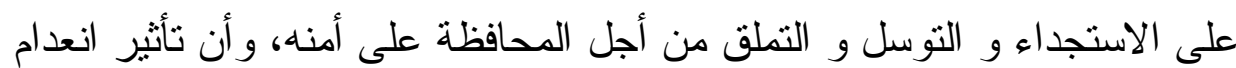

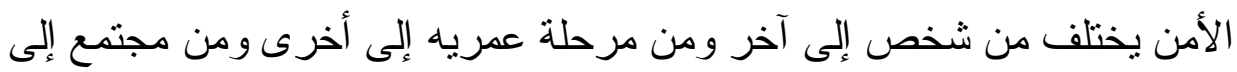


ا. ابن منظور (ب،ت): قاموس لسان العرب، دار المعارف، القاهرة. r. أبو بكرة، عصام (ب99 (1)): العلاقة بين القيم الدينية و الأمن النفسي لدى طلبة جامعة اليرموك، رسالة ماجستير غير منشورة، جامعة اليرموك، الأردن. r. أبورحيم، محمد (990 (1)): علاقة سمات الثخصية بمشكلات التو افـق فـي المر اهقة، مجلة در اسات، العلوم الإنسانية، الجامعة الأردنية، مجلد r Y، العدد

؟. أبو عودة، محمود (T . ץ): در اسة لبعض الاتجاهات السياسية و الاجتماعبــة

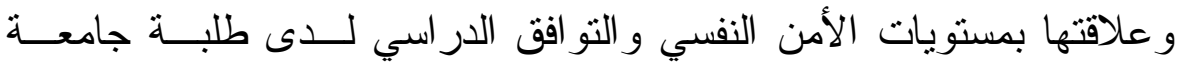
الأزهر بغزة - رسالة ماجستير غير منشورة، كلية التربية، جامعة الأزهر، ولهي

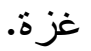
0. البشيتي، محمد نظام (0 ץ): رؤية في سيكولوجية الطفل الفلسطيني، مجلة

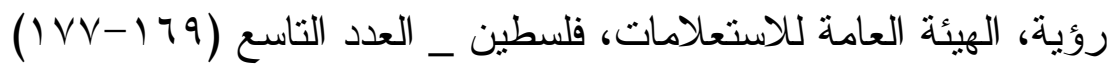
T. التبريزي، محمد بن عبد الله (919 (1): تحقيق، الألباني مشكاة المصابيح،طب المكتب الإسلامي، بيروت.

V. الترمذي، محمد بن عيسى (Y79 ( )): الجامع الـصحيح، مطبعــة الحلبــي،

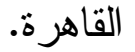
^. التل، شادية و أبوبكرة، عصام (997 ()): تطوير مقياس الأمن النفـسي فـي

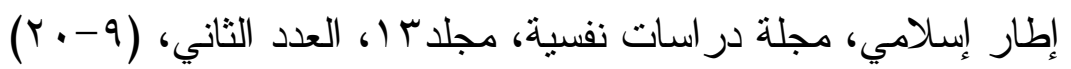


9. الحفني، عبد المنعم (؟9 99 (): موسوعة علم النفس و التحليل النفسي، مكتبــة

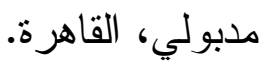

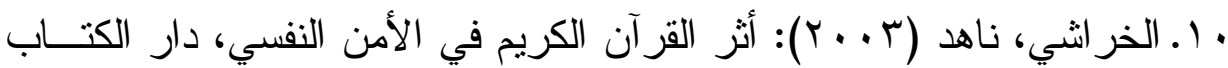

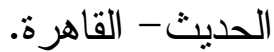

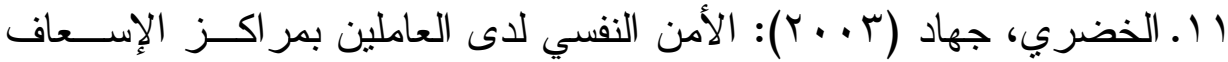
بمحافظات غزة و علاقته ببعض سمات الثخصبة ومتغير ات أخرى، رسالة الآن ماجستير غير منشورة، الجامعة الإسلامية، غزة. ب ا. الخليل، أحمد (1991) (الثعور بالأمن النفسي عند الطلبة المــر اهقين فـي

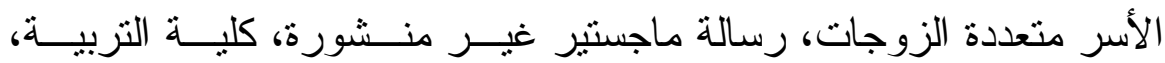

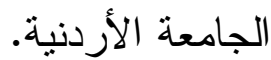

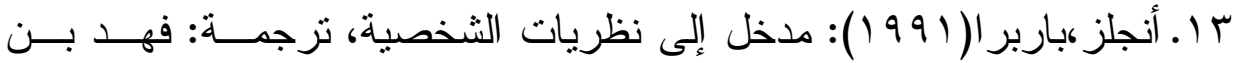
دليم- دار الحارثي للطباعة و النشر ، الطائف. ـ ا. الريحاني، سليمان (910 (1): أثر نمط التشئة الأسرية في الثعور بـالأمن،

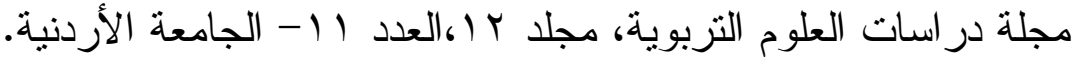

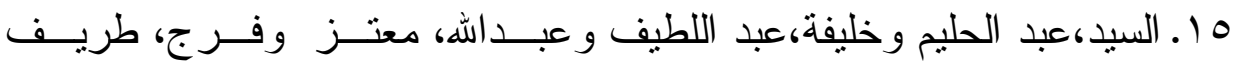

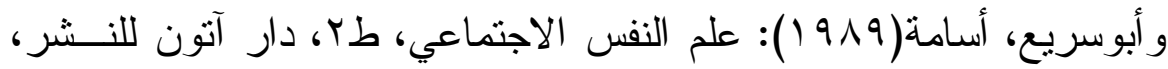

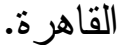

7 (. الصنيع، صالح ( •99 1): در اسات في التأصيل الإسلامي لعلم الــنفس، دار

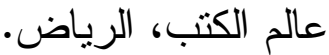
V V العتوم، عدنان (99V (1)): أثز سماع القر آن الكريم على الأمن النفسي، مجلة

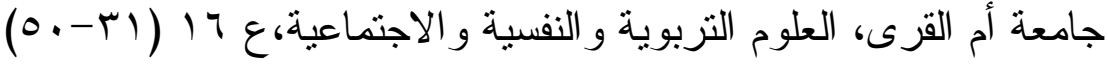


11 ـ الكناني، صلاح (911 ()): مدى تحقق التظظيم الهرمي للحاجات عند ماسلو،

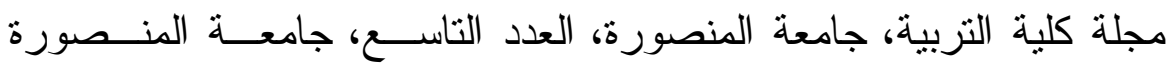
$(|r Y-\lambda|)$

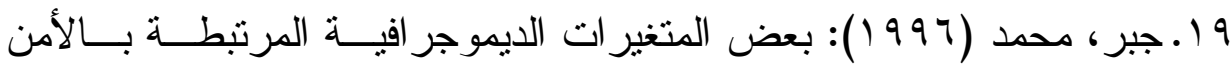

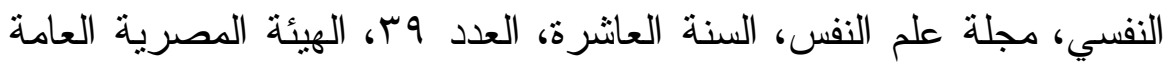

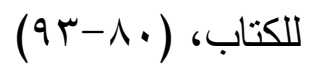

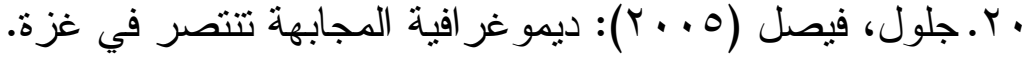
www.alarabnews.com/alshaab

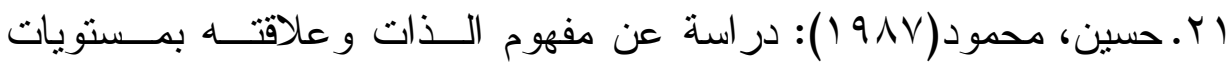

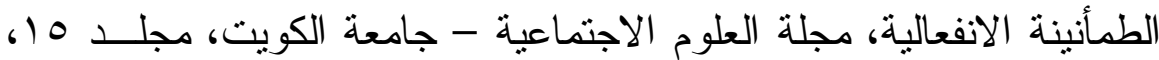

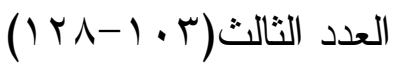

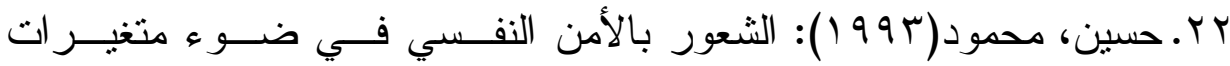
المستوى و التخصص و التحصيل الدر اسي لدى طلاب المرحلة الثانوية فــي مدينة الرياض: النمو الانساني ( الطفولة و المر اهقة ) جدة - دار الخريجـي

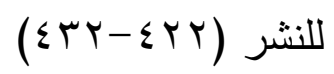

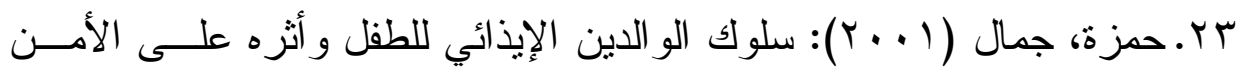

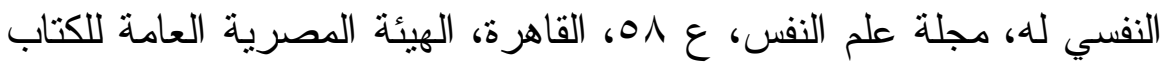

$$
(1 \leqslant r-\mid r \wedge)
$$

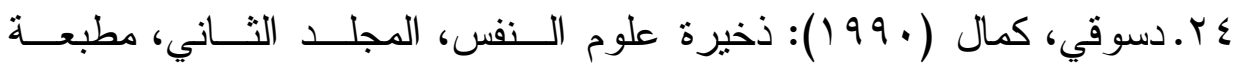

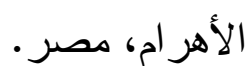


Or.دواني، كمال و دير اني، عيد (r/911): اختبار ماسـلو للـشعور بــالأمن

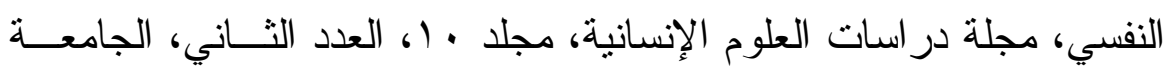

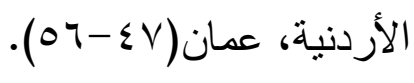

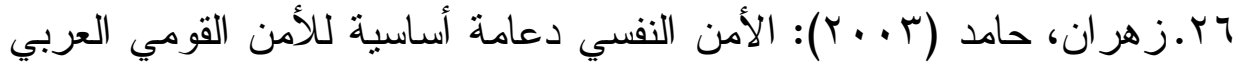

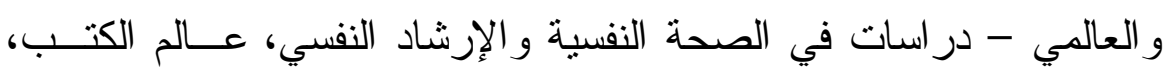

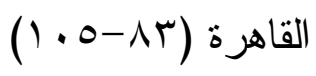

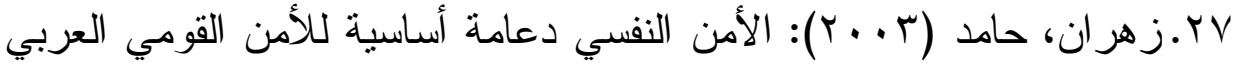

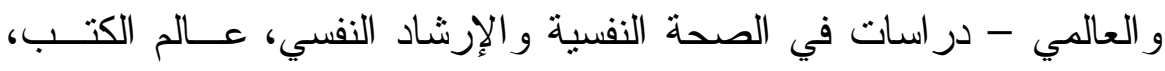

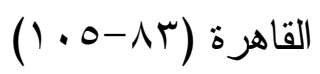

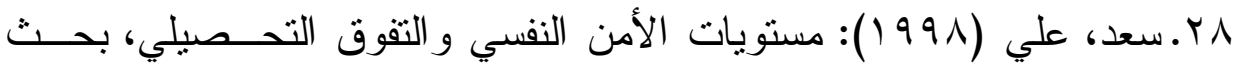

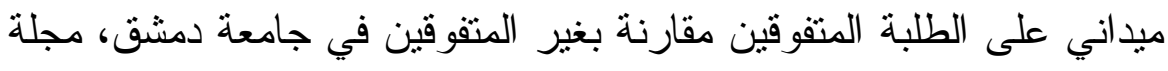

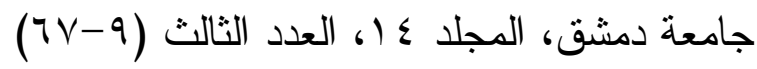

9 Y. سعد، علي (999 (199): مستويات الأمن النفسي لاى الثباب الجامعي_ بحــث

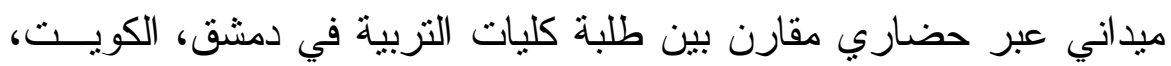

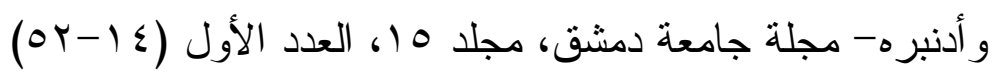

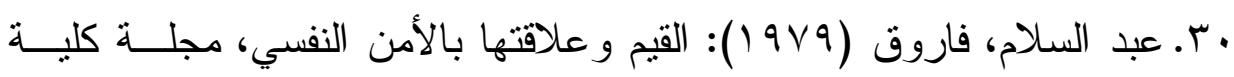

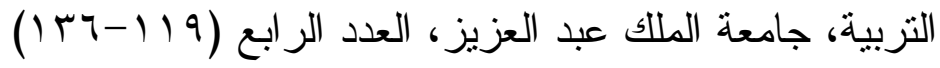

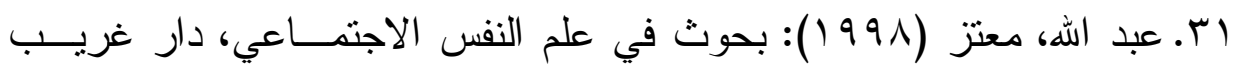

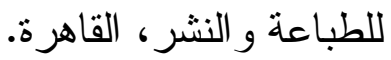




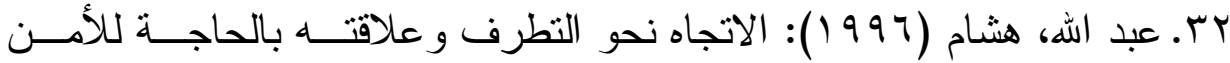
النفسي لدى عينة من العاملين وغير العاملين، مجلة الإرشاد النفسي- العدد

$$
\text { الخامس، جامعة عين (•rV-r) }
$$

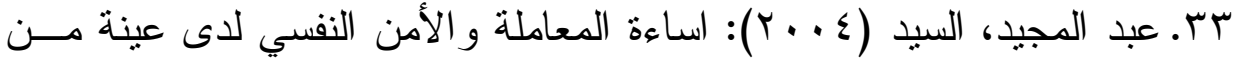

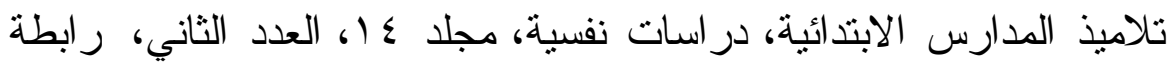

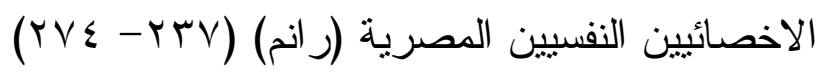

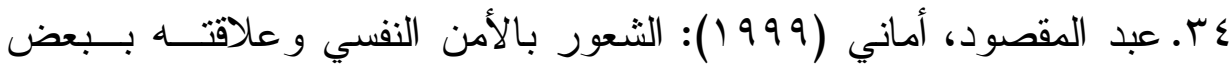

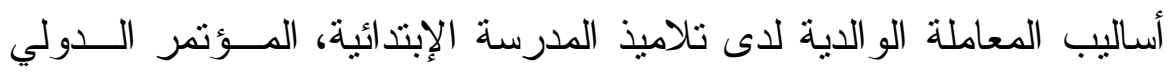

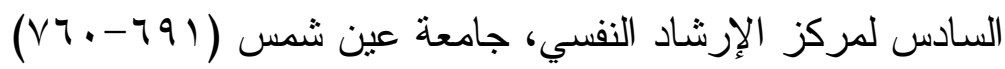

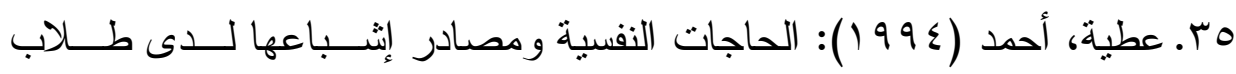

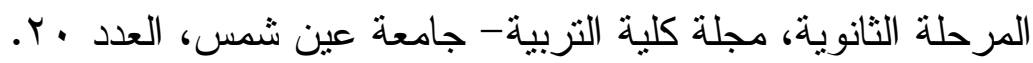

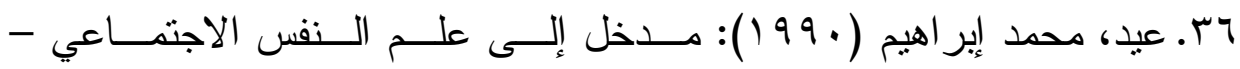

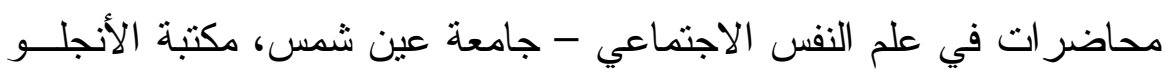

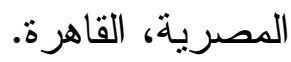

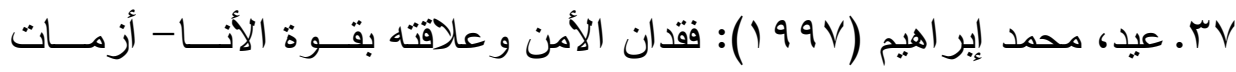
الثباب النفسية مطلوب دار النشر، القاهرة.

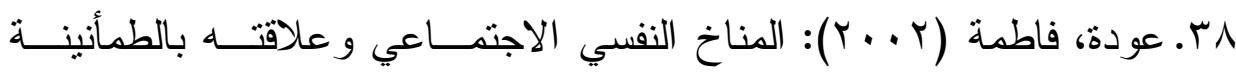

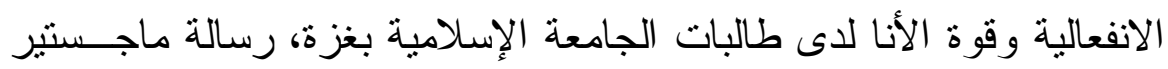
غير منشورة- مكتبة الجامعة الإسلامية، غزة. 


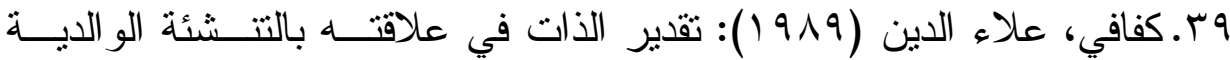

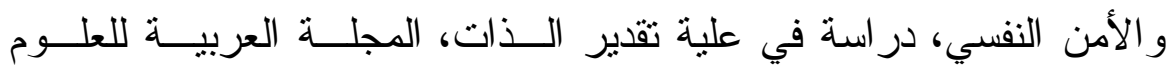

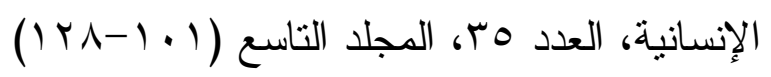

• ـ ـ محمد، شعبان (Y991 (1): در اسة بعض مكونات الحاجز النفسي بين المو اطن

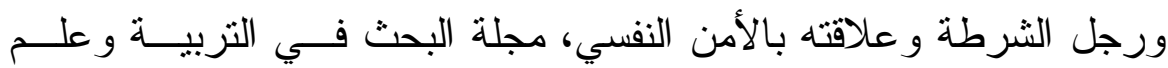
النفس، العدد الر ابع، المجلد 10 ـ كلية التزبية، جامعة المنيا.

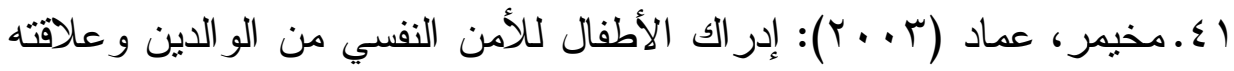

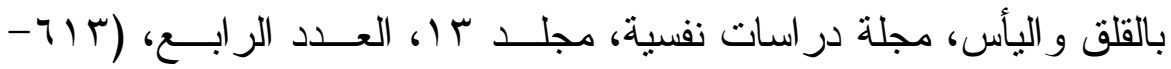

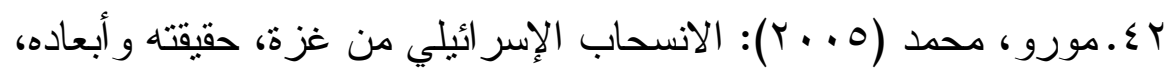
http://withdraw.sis.gov.ps

بـــموسى، رشاد و باهي، أسامة (919 (1): النسق القيمي وعلاقته بالطمائنينــة

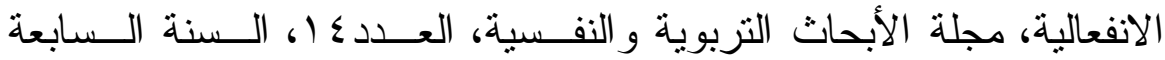

(1) $11-9 v)$

42-Davis, Patrik Eital (1995): Children`s Responses To Adult Conflict As A function Of Conflict History, Eric- No.Ed 390528.

43-Fogarty, Gerald \& White, Colin (1994): Differences between Values of Australian Aboriginal and NonAboriginal Students, Journal of Cross Cultural Psychology, Vol 25 (394-408) 
44-Londerville,Susan \& Main, Mary (1981): Security of attachment, Compliance, and maternal training methods in the second year of life. Developmental Psychology- vol 7, (289-299).

45-Robert, John E (1996): Adult Attachment Security And Symptoms Of Depression, Vol 70, No 2.

46-Vohra, Robert \& Sen, Arthur (1986): A study Of Rigidity And Security Among High Anxiety And Low Anxiety Groups Of Married Women, Social Science International, Vol 2,(37-43). 